\title{
Transatlantica
}

Revue d'études américaines. American Studies Journal

2 | 2014

Aesthetics of Theory in the Modern Era and Beyond / Photographie documentaire

\section{The Politics of Aesthetics: Ezra Pound's Jefferson is Mussolini}

\section{Hélène Aji}

\section{(2) OpenEdition}

\section{Journals}

Electronic version

URL: https://journals.openedition.org/transatlantica/7135

DOI: 10.4000/transatlantica.7135

ISSN: 1765-2766

\section{Publisher}

Association française d'Etudes Américaines (AFEA)

\section{Electronic reference}

Hélène Aji, "The Politics of Aesthetics: Ezra Pound's Jefferson is Mussolini", Transatlantica [Online], 2 I 2014, Online since 03 February 2015, connection on 01 February 2023. URL: http://

journals.openedition.org/transatlantica/7135 ; DOI: https://doi.org/10.4000/transatlantica.7135

This text was automatically generated on 1 February 2023.

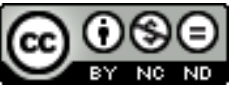

Creative Commons - Attribution-NonCommercial-NoDerivatives 4.0 International - CC BY-NC-ND 4.0

https://creativecommons.org/licenses/by-nc-nd/4.0/ 


\title{
The Politics of Aesthetics: Ezra Pound's Jefferson is Mussolini
}

\author{
Hélène Aji
}

It will be necessary here to return to the historiographic questions raised by the use Ezra Pound makes of historical characters, in the Cantos and elsewhere, ${ }^{1}$ placing his own words in their mouths and drawing parallels that often defy documents, events and their general accounts by historians. Within the general frame of Pound's theory of the "luminous detail," the attention paid to facts and the accuracy of reference by such as Carroll F. Terrell ${ }^{2}$ or Tim Redman, ${ }^{3}$ might resort more to erudition than to a dynamic evaluation of Ezra Pound's strategic decisions in inscribing historical facts under the sign of a highly idiosyncratic master narrative: the reformulation of historical accounts wills itself into performativity, amounting to an actual reforming of history, in the sense of its reshaping, reorganizing, and redirecting. If Pound is indeed very aware of the theoretical ramifications of his aesthetic decisions, up to the point of integrating the aesthetic statement to the poem both in the conceptual import of its statements and in the formal experiments it evidences, it seems that he is also working towards the definition of a politics of aesthetics. If the terms are the same as those used by Jacques Rancière in his famous interview "The Distribution of the Sensible," it is however to return to their origins in the Benjaminian analysis of an "aestheticization of politics," one that ties in with the ideological forces at work in between the world wars and which was of major consequences on the evolution of some of the arts towards extreme forms of avant-gardism and extreme forms of political commitment, until the thin line between the ethical demands of historical narration, and the aesthetic objectives of artistic creation became, at least temporarily, blurred:

[For Rancière,] There is thus an 'aesthetics' at the core of politics that has nothing to do with Benjamin's discussion of the 'aestheticization of politics' specific to the 'age of the masses'. This aesthetics should not be understood as the perverse commandeering of politics by a will to art, by the consideration of the people qua work of art. If the reader is fond of analogy, aesthetics can be understood in a Kantian sense-re-examined perhaps by Foucault-a the system of a priori forms determining what presents itself to sense experience. (Rancière, 8) 
2 Actually it would seem that for Walter Benjamin, the inscription of an "aesthetics of politics" in his time does not simply reflect the modus operandi of propaganda, a way of seducing the masses into beliefs through aesthetic agreement, beyond the bounds of rationality. It could very well point at the surprising convergence of the expressive modes of modernist impersonality, and the fascistic tendencies to erase the moral demands of individual integrity. There is thus at times an uncanny correspondence between the politics of Fascism and Ezra Pound's aesthetics. In Pound, Fascism emerges at the end of a whole process of utopian disillusionment in the possibilities of enforcing an anti-capitalistic economy in a sophisticated civilization, respectful of the grandeur of the past yet adapted to the advances of modernity, so that it is probably the most visible and reprehensible facet of a more general interlocking of politics and aesthetics. In this specific case, the interaction between the Benjaminian aesticization of politics, and aesthetics as providing the categories to perceive of politics, more along the lines of Rancière's theory, is complex and leads to what may seem to be a perilous balancing act:

That Pound could apparently accommodate both these ravings and a "sophisticated" modernism in this period might seem surprising; but the writer would have seen no conflict here. Pound could easily switch from his Hitlerian fantasies to a recommendation of the kind of artists (Joyce, Marinetti) that the Führer would have classed as "degenerate." In his mind, the sharp lines of modernism seem to have been equated or even interchangeable with the totalitarian politics of Nazi Fascism. This balancing of diverse political and esthetic drives was a project with which both Marinetti and Pound were involved. (Barnes, 32)

3 Yet in what can be seen as Pound's politics of aesthetics, the text does not so much convey and enforce its theoretical, potentially self-reflective, presuppositions, as it signals the necessary political significance of any text, the ideological dimension of every choice presiding over its production, and the consequent relations that link together texts and figures of varying times and heterogeneous origins, under the sign of an assumed kinship in aesthetics and in politics. This moves beyond, and virtually diverts the Benjaminian analysis of Fascism as the aestheticization of politics, which Benjamin evokes in "The Work of Art in the Age of its Mechanical Reproduction," since his argument points mostly at the developments in mass culture. Ezra Pound might be seen as pulling back together what Benjamin sees as two opposed "polar" points of art reception: for Benjamin, "Works of art are received and valued on different planes. Two polar types stand out; with one, the accent is on the cult value; with the other, on the exhibition value of the work" ("The Work of Art in the Age of Mechanical Reproduction" V); for Pound, the ritualistic value of art and its exhibition value are not antagonistic, but two forces that need combining... in modes that seem to be fully achieved in the "art" of Nazi spectacle. Benjamin's analysis is useful, but it is more problematic than it first seems:

Perhaps the most common starting point for literary discussions of Fascism is Walter Benjamin's claim that Fascism is the aestheticization of politics. This judgment, which has acquired the status of a truism, is rarely discussed in any detail, yet it hides a variety of problems. First, the quote comes from Benjamin's essay "The Work of Art in the Age of Mechanical Reproduction," the title of which refers to visual art: paintings, sculpture, architecture, theatre, and film. In the Epilogue, Benjamin notes that the mass visual culture that has resulted from mechanical reproduction has been utilized by Fascist regimes as a means of reinforcing their power and distracting their populations from the problems of 
property relations. Benjamin is critiquing not aesthetics per se, but the relatively

new developments in mass spectacles. (Freind, 547)

In Benjamin's own words, the dialectics amounts to a form of hijacking of aesthetics by rogue politics, through the technological devaluation of the "aura" of the authentic. The outcome is war, and its outrageous aestheticization in a "self-alienation" that cannot but bewilder: the masses end up longing for the perverse sacralization of their own enslavement and destruction:

The growing proletarianization of modern man and the increasing formation of masses are two aspects of the same process. Fascism attempts to organize the newly created proletarian masses without affecting the property structure which the masses strive to eliminate. Fascism sees its salvation in giving these masses not their right, but instead a chance to express themselves. The masses have a right to change property relations; Fascism seeks to give them an expression while preserving property. The logical result of Fascism is the introduction of aesthetics into political life. The violation of the masses, whom Fascism, with its Führer cult, forces to their knees, has its counterpart in the violation of an apparatus which is pressed into the production of ritual values.

All efforts to render politics aesthetic culminate in one thing: war. (Benjamin "Epilogue" to "The Work of Art in the Age of Mechanical Reproduction")

What is in fact more relevant to Pound is the possibility of a more intricate relationship between aesthetics and politics, which includes but does not limit itself to the Fascist case. In this respect, the instance of Sigismundo Malatesta ${ }^{4}$ in the "Malatesta Cantos," has been well studied, notably by Lawrence Rainey, and Tim Redman: both underline the way the archival work to dig up Sigismundo Malatesta's story is superseded by the demands of both romanticization (aestheticization), and exemplariness (politicization), to the extent that it becomes a case in point to demonstrate the Poundian process of simultaneous historicization and poeticization. Under Pound's supervision, the architecture of the Tempio d'Amore comes to embody the independence, economic and political, of a pre-Capitalist Italy, free from the fetters of money to invent the aesthetic Renaissance. If this is for the most part fiction, and a very inventive and questionable reading of the archival material in the light of crypto-Fascist reinventions of the modern Italian man, it more symptomatically points to the intrinsic link made between the political structures and the aesthetic options of a given time and place. To a certain extent, Pound puts into practice a theory whereby aesthetics informs the politics of an era, as much as it is informed by it: in Pound's view, the assumed fin-de-siècle detachment of the arts is over, which entails a revision of the entire history of the arts and literature, and this revision happens in the light of such characters as Malatesta, whose patronage of the arts is seen as much more significant than personal interest, since it comes to embody a superior awareness of both the "politics of aesthetics" (Rancière) and the "aesthetics of politics" (Benjamin) as at work simultaneously and in conjunction. Whereas this is not explicitly phrased in his diverse attempts at underscoring this revised mapping of "Kulchur," 5 it does become a central debate in the works of poets that more or less willingly claim the Poundian heritage: in "Pounding Fascism," for instance, Charles Bernstein reflects upon the political consequences of a poetics of citation such as practiced by Ezra Pound. His writing, revolutionary as it is in terms of its techniques, and its "impact," 6 indeed falls into the 
realm of this "consciousness constituting activity of ideology," one which the poet, with Pound, tries to control and master, and, with Bernstein, tries to underscore and denounce:

The use of preexisting or source or found materials in poetry and the other arts remains an occasion of political concern. Are these materials permitted to exist in and for themselves as inviolable artifacts-or are they appropriated into a frame that invests them with specified meaning determined by the author's ideological position? Or are they debauched and defused as mere codes, empty signifierstrophies for a postmodern library? The double bind of impossible universal or historical truth versus a fraudulent narrative invention is no more than the shadow play of those who do not wish to live in any here or now. It is possible for poetry to make the consciousness constituting activity of ideology audible, to respect the origins of words and to invent new worlds for them. This project persists. (Bernstein, 127)

6 The evolution in Pound's choice of personae from the fictitious Hugh Selwyn Mauberley to the literary Sextius Propertius and philosophical Confucius (to name but a few), on to the political figures of America's and Italy's past and present, is a movement which increasingly emphasizes the aspiration to a usable poetry, at the same time as it performs increasingly powerful assimilations or identifications between the figures involved. It does not demystify the ideological forces at work in poetic expression, but attempts to harness them to serve a project that has aesthetic and political implications. With the two versions of Jefferson and/or Mussolini, the first in English, written in 1933 and published in 1935, the second in Italian, a sometimes approximate translation, published in Venice in 1944, one can perceive a shift which is evidenced in the ambiguities of the title's translation: the Italian Jefferson $e$ Mussolini has lost the possibility of an alternative, the signal of a deliberate substitution, to privilege parallelism. However, the Italian coordination "e" puns on the Italian verb "è," opening up the title to a new interpretation: "Jefferson è Mussolini," translating back as "Jefferson is Mussolini." Far from its suggestive American title, still fraught with hesitation between a parallel and a substitution, the Italian version of the text asserts the identification between the two, bringing Pound's rereading of history to the extreme of a rewriting of history. This importance of the Italian text to understand the evolution of Pound's political personae accounts for the use, here, of specific comments on the Italian version, which is Pound's own; references to the English original are in the footnotes for further comparison. From what was a hypothetical proposal in 1935, Pound moves on to the redaction of a monument to a Fascist reenactment of American agrarianism. This argument is compounded with the fact that Jefferson e Mussolini, a text of propaganda in favor of a vacillating Fascist regime, is also produced as a response to Pound's reading, in Italian, of Louis-Ferdinand Céline's pamphlets, notably Bagatelle pour un massacre, thus turning the Italian language into a locus for the radicalization of previous political and aesthetic strategies. When writing in Italian, Ezra Pound opts for a language that stems directly from the aesthetic and political project of Dante.

7 Thus Pound's mode of appropriation, appearing in his use of quotes and translations, when applied simultaneously and equally to the poetic and to the historical, generates a number of problems, which strategically pull the poem away from the aesthetic and push it toward the didactic. Conversely, this same tactic could be seen as Pound's aesthetic and political response to the aesthetics of politics which Walter Benjamin finds exemplified in Fascism. This and the questionable choices made by Pound have led to a form of schizophrenia in Pound criticism, triggering aestheticizing attempts at 
rehabilitating the poet at the expense of the political man. But these do not take into account the very aesthetic dimension which attracted Pound towards Fascism, one which led him to define the Duce in terms of the genius and the artist. As pointed out by Bernstein in "Pounding Fascism," the power of Poundian poetics lies precisely in the assertion of poetry's relevance to the world we live in and in its volitionist inflections. Thus Pound's evaluation of Jefferson directly leads him to considerations of genius and to an organic vision of "germinating ideas":

Le barzellete anti-democratiche, ed anti-jeffersoniane, di moda recente sono giunte alla supposizione falsa che Jefferson ebbe delle idee fisse. Nel suo tempo lo stesso tipo d'idiota che oggi lo disprezza, attaccava in senso contrario, cioè biasimava Jefferson perché le sue idee non erano idee fisse. La fissazione dell'idea era precisamente la forma d'idiozia della quale Jefferson era incapace. Non aveva idee rigide, verniciate, in vacuo. L'idea d'un genio, le idee del genio sono organiche, germoglianti come le seme. Mettete una tale idea in situ, mettetela in un dato tempo o luogo, e qualche cosa succederà. (Pound, 1995, 36) ${ }^{7}$

From the denial of fixed ideas which opens Jefferson e Mussolini, Pound moves on to the thematics of action and activity in language. Interestingly enough, in the Italian pamphlet, this activity is likened to the activity of the poet "gathering the fragments of the mosaic" in the same manner as he had previously "gathered the limbs of Osiris" (in The New Age of 1911):

Continuo a raccogliere i frammenti del mosaico. (Pound, 1995, 41)

Pound believes in the performative power of both the Duce's and the poet's language, in the common ability of their words to achieve things, so that, in Peter Nicholls's words, "one key to Pound's response to fascism lies in this characteristic emphasis on a renovated and dynamic language." (Nicholls, 97)

The paradoxes of Pound's poetry, which it might be tempting to dismiss by insisting on the "difficult" beauty of the poems, are in fact what makes him so significant to today's poets and to their projects to write more than ornamental or playful texts. If, for the sake of Pound's moral salvation, one concentrates on the beautiful poem, and neglects what this poem intends to say and to perform, one implicitly and more generally adheres to a poetry without content, befitting Giorgio Agamben's "man without content." On the contrary, and this is what this article is addressing, recognizing and coming to terms with the consequences of Pound's untenable decisions is what shapes a poetry aware of the powers at work in language and intent on exhibiting them, thus outlining the conditions of man's existence and achieving one major aspect of the Poundian program.

\section{II}

11 The dialectic of the political man as artist (or poet) is what symmetrically enables Pound to construct his own persona: a figure of the poet as political man.

Pound insists that no estimate of Mussolini is valid unless it treats him as an artist [...]. Who possibly was in a better position to judge the work of a fellow artist than Pound, one of the preeminent critics of this century? Thus, by a neat shift of ground, Pound became a political authority. This shift of ground allowed to occupy two worlds of differing values; it also eased Pound's identification with his hero, Mussolini. (Redman, 118) 
This issue of identification, which Tim Redman underscores here, is much more complex than it seems at first sight because it does not simply involve one figure, which would be Mussolini, nor does it remain unambiguous. The process works both synchronically and diachronically, generating a specific conception of time, both dynamic and static: on the synchronic axis, Mussolini is the peer of many a contemporary sculptor, briefly compared to Gaudier, more often to Picabia and Brancusi. In this, Peter Nicholls points out, Pound relays Mussolini's self-definitions and in particular his vision of himself as the "sculptor" of the people (Nicholls, 96):

For the sculptor, thought is immanent in constructive activity; 'theory' is not the province of logic and abstraction, but the 'form' determining the course of action. One can see how such an idea might relate to the energised dialectic of the middle Cantos, but put this way it is far more ambiguous than notions of the "poet as sculptor' recognise. In this sculptural analogy, 'form' is seen to arise from an inherent idea, and not from a nexus of contingencies. The model of the sculptor suggests, in fact, a self-constituted and self-legitimising authority. Mussolini used it to enforce his ideal of the leader 'moulding' his people, but in so far as Pound was beginning to endorse such conceptions, so his own view of the relation of writer to reader would undergo some radical changes. (Nicholls, 96-7)

This conception of the politician and of the poet as "sculptor" is far from neutral and founds superimposed visions of politics as shaping society and of poetry as shaping the mind of the reader, in a literalization of the notion of information as magisterially giving form to the inferior formless. As Bob Perelman puts it, "such metaphors are crucial for Pound: the artist, ruler, sage, sun, is superior to and separated from his material, which he controls, sculpts, canalizes, illuminates, renders clean by sharp demarcations" (Perelman, 66).

From a diachronic point of view, Pound tries to evidence the repetitivity of history and the consequent applicability of past notions (such as Dante's directio voluntatis) to all phases of history. Mussolini is not just to be compared "and/or" identified to Lenin, but also and above all to Thomas Jefferson. The idea of models, to which Nicholls alludes (96), might be replaced with the idea of returning figures in a rhythmic "orchestrating" of history (McMahon, 83), which has a lot in common with Pound's own orchestration of his poetic text. The prosody which he refers to in Jefferson e Mussolini is order imposed on irregularity-a notion which can apply indifferently to the poem and to "l'idea statale," the "idea of state": "Il vigore della prosodia "regolare" deriva da un movimento irregolare sottostante" (Pound, 1995, 89-90). . And indeed, Pound's Jefferson $e$ Mussolini, the 1944 Italian version of the 1933 Jefferson and/or Mussolini, privileges the option of assimilation: in times of crisis and radical doubt, the comparison disappears so that synchronic and diachronic distinctions are lost and the various individuals and figures, in their diverging contexts and trajectories, fuse to compose a stabilized figure for the poet. This action of subjectivity, which erases differences, is one claimed by Pound himself in the course of his pamphlet: it belongs to the man of genius of whom he is speaking, as well as to himself, and is to be integrated into a more general theory of perception.

L'uomo di genio, come ebbi occasione di dire a proposito dell'opera cinematografica di Francisci, ha la capacità di vedere dieci cose dove l'uomo medio non ne vede che una, e dove l'uomo abile ne vede due o tre; in più l'uomo di genio è capace di registrare la sua percezione multipla nella materia della sua arte. [...] Jefferson era polumetis, di mente multipla. (Pound, 1995, 83-4) ${ }^{10}$ 
Con tutte le diversità superficiali, né Jefferson né Mussolini è gongorista, coiè essi non oscurrano il totale con dettagli. Jefferson, uomo di legge, adoperò la fraseologia della legge come strumento, come ordigno. Mussolini, ex-direttore di giornale, adopera il giornalismo, ed in confronto delle consuetidini linguistiche italiane, il modo della sua eloquenza merita attenzione. $(67)^{11}$

La percezione non è solamente un segno della soggettività personale, ma la percezione vera dell' esistenza d'un oggetto che un altro percepe. [...] o forse l'intuizione abbracia il complesso e vede diritto, il posto-ricevente verbale, o la logica, apprende solamente i dettagli isolati; l'intuizione, essendo incapace di afferrare il detaglio particolare, registra solamente il totale. (57-8) ${ }^{12}$

In this perspective, the idea of totalitarianism takes on a discrepant as well as wider definition, since Pound seems to justify it as part of a more general quality, one that ties together conceptualization and action. Pound's sense of "total perception" is linked to his theory of culture, in that it dispenses with the exposition of facts and argued hypotheses which characterizes conventional scholarship in favor of the radiance of the "luminous detail." Acceptance is, according to him, necessary because of the very concreteness of his vision, a concreteness which cannot but recall the "intellectual and emotional complex in an instant of time" that makes up the image, but with the notable difference that this complex has now become impervious to time or the times, detached from unsettling details and facts, a hieratic petrifaction of perception into what becomes called "intuition." Pound does not fail to see the arbitrariness underlying this definition of intuition and its legitimization, but the question he asks in Jefferson $e$ Mussolini is little more than purely rhetorical, a preterition that is in actuality a reminder of the self-proclaimed and self-imposed duty to believe and adhere: "Ma perché devo io, confuciano e jeffersoniano, accettare un sistema tanto diverso in apparenza, e nei particolari?" (Pound, 1995, 55). ${ }^{13}$ Why should he (or indeed, why should we) accept the systemic nature of his vision, and its subsequent suppression of difference and detail? It would be in the name of perception, intuition and subjectivity, or so we are told. What seems obvious to the Poundian subject is to be recognized as the "Mussolinian miracle" by all others, regardless of epoch or nation. Each and every one of them is thus turned into a vehicle for Pound's ideas: "Frobenius ha definito il miracolo mussoliniano: il risvegliarsi del senso di responsabilità. Lo cito per sentire la mia propria opinione espressa da un competente" (Pound, 1995, 48). ${ }^{14}$

But as Pound inadvertently signals, this belongs to a whole process of "reading into," a quest for what is desired among the strange, and often misunderstood, signs of otherness and alienation. Thus, because one cannot find in his prose or in his poetry any chronologically or rationally organized vision of history, Pound's assertions do not cease to bewilder. His claim for honesty and responsibility, once embodied by the "morally ambiguous figures" of "Bertrans de Born, Odysseus, El Cid, and Sigismundo Malatesta" (Redman, 103), not to speak of Benito Mussolini, loses a great deal of its credibility: these men, in Tim Redman's words, were "seldom bound by legal codes or ethical scruples, and Mussolini is no exception." (Redman, 103) Redman himself stresses the oscillation between "fascination" (103) and "a great deal of confusion" (109), the insistence on convergence instead of divergence, the paradoxical attachment to crystallized ("fixed") vision as well as to the mutability of ideas in action. The tension which Redman underlines between the form of the pamphlet and the coherence of the political vision is indeed "typical of Pound" (116) insofar as it traces the difficulties and hesitations of a forceful unifying intention. 
Pound's eclecticism, in matters of both politics and economics, is the source of a great deal of the confusion about his views during this period. He insisted upon using what he considered to be the best features from differing economic and political systems. He tried to bring people bent on reform into agreement by emphasizing how their views converged rather than diverged, an activity that was puzzling or incomprehensible to many of his more doctrinaire correspondents. (Redman, 109)

Now it "is not difficult to see the relation between this political ideal of Pound and his ideas about activity and progress in the arts, although it is difficult to reconcile his views with our understanding of Jeffersonian democracy" (Redman, 117-118). In the wake of Brooks Adams, Pound places his view of history and politics under the sign of tragic decay. In the wake of Van Wyck Brooks, he tries to make it coalesce into a "usable past." The roots of American democracy are to be found in the ethics and politics of the first settlers and later in the Declaration of Independence, but he sees American industrialization in the nineteenth century as nothing but a perversion of the original ideals. The fundamental purpose of the American state has been lost in the process, and according to Pound it has been lost to "usura."

"Usura," "the beast with a hundred legs" of "Canto XV" (Pound, 1986, 64), is the reason why states fail to develop harmoniously and undergo cycles of booms and depressions, the reason why the agrarian beauty of the Jeffersonian mansion has been lost to the world... but might be retrieved by the neo-Classical and pseudo-Roman constructions of Fascist Italy. Usurers use the power of money to keep states and peoples under their control; and they use words in a similar fashion, preventing them from being Flaubertian "mots justes," adequate, legitimate, and final:

and with Symons remembering Verlaine at the Tabarin

or Hennique, Flaubert

[...]

To communicate and then stop, that is the

law of discourse

To go far and come to an end (Pound, "Canto LXXX," 1993, 514)

For Pound, this is particularly obvious in nineteenth-century America and is contrary to the ideals of the eighteenth century. The political philosophy that informs the works of John Adams and Thomas Jefferson, his only sources on the American Revolution and the subsequent birth of the nation, is colored with the Enlightenment's valorization of the individual, democracy, and of equality. However, it is also from these works that he derives his faith in the power of the individual to generate massive political change and his protest against what he sees as the degenerate world of industrial America. Of course, this view is largely informed by the anti-liberal ideology pushed by Fascist ideology in Italy. Paradoxically, then, two types emerge from Pound's vision of politics, one which likens the individual to a candle whose light is only brighter when combined with the light of thousands of other like candles; and the other which singles out one exceptional individual whose superior vision allows him to guide the masses.

\section{Conclusion}

Bob Perelman underlines the mystical dimension of the Poundian enterprise, one which does not redeem it but which allows to think about the relations between society 
and poetry, politics and aesthetics: Pound's ideal state or city is, in Perelman's phrase, "a poem-society," generated by the ideogrammic method as idiosyncratic language.

The ideogrammic method was not a specific poetic technique or rhetorical effect: it was language speakable only by a hero or genius, and it entailed a vision of a simultaneously natural and hierarchical society-Pound's China or his Italy-where poetry was central and the center was poetic. Only in such poem-societies would ideograms have the meanings claimed for them: language would not be contaminated by abstraction or deadened by cliché; it would be a totalized medium stretching in an ordered and energetic continuum from the state to nature. (Perelman, 60-61)

It is no wonder then if the "disjointedness" of Jefferson and/or Mussolini, and subsequently of Jefferson e Mussolini, strangely reminds the reader of the fragmentation of the Cantos (Redman, 116). Nor is it too surprising to notice that the thirty-two sections of the pamphlet echo the thirty-two cantos already composed in 1933. Ezra Pound's "project persists," in Bernstein's words, to turn his aesthetics of politics into a politics of aesthetics, and thus usher in the era of the poet-dictator, a ruler over word and world. In doing so, it irredeemably taints the political commitment of the poet, and raises the equally persisting question of the unfathomable risks taken by such as Pound that forced aesthetics to attempt a retreat to the neutral, but self-deluded and disempowered, ground of apolitics. In this "poem-society," the medium is an obstacle, truth is elusive and relative, and the text awaits the ethical turn that would signal the advent of a "politics of aesthetics" under other conditions, a politics and aesthetics of "resistance" (Zizek in Rancière 75).

\section{BIBLIOGRAPHY}

Works cited:

ADAMS, Brooks, The Law of Civilization and Decay: An Essay on History, New York, Macmillan, 1896.

AGAMBEN, Giorgio, Man without Content, Stanford, Stanford University Press, 1999.

BARNES, David, “Fascist Aesthetics: Ezra Pound's Cultural Negotiations in 1930s Italy," Journal of Modern Literature XXXIV 1 (2010) 19-35.

BENJAMIN, Walter, "The Work of Art in the Age of Mechanical Reproduction" (1936), Published by Schocken/Random House, ed. by Hannah Arendt, https://www.marxists.org/reference/ subject/philosophy/works/ge/benjamin.htm. Accessed Oct. 7, 2014.

BERNSTEIN, Charles, "Pounding Fascism (Appropriating Ideologies-Mystification, Aestheticization, and Authority in Pound's Poetic Practice)," A Poetics, Cambridge, Harvard University Press, 1992, 121-7.

BROOKS, Van Wyck, “On Creating a Usable Past,” The Dial 54 (11 April 1918).

FREIND, Bill, “ 'Why do you want to put your ideas in order?': Re-Thinking the Politics of Ezra Pound," Journal of Modern Literature XXIII 3-4 (2000) 545-63. 
MCMAHON, Fiona, “Orchestrating Rhythms in the Wake of Ezra Pound's Interpretative Prosody," Hélène Aji, ed., Ezra Pound and Referentiality, Paris, Presses de l'Université de Paris-Sorbonne, 2003, 83-92.

NICHOLLS, Peter, Ezra Pound, Politics, Economics and Writing, Atlantic Highlands, Humanities Press, 1984.

PERELMAN, Bob, The Trouble with Genius: Reading Pound, Joyce, Stein and Zukofsky, Berkeley, University of California Press, 1994.

POUND, Ezra, A Guide to Kulchur (1938), New York, New Directions, 1938.

---, "I Gather the Limbs of Osiris" in Selected Prose, Cookson, William, ed., New York, New Directions, 1973.

---, Impact: Ezra Pound's Essays on Ignorance \& the Decline of American Civilization, Stock, Noel, éd. Chicago, H. Regnery Co., 1960.

---, Jefferson and/or Mussolini, New York, Liveright, 1935.

---, Jefferson e Mussolini, Milan, Terzaria, 1995.

---, The Cantos, London, Faber, 1986.

---, The Cantos, New York, New Directions, 1993.

RAINEY, Lawrence S, Ezra Pound and The Monument of Culture: Text, History, and the Malatesta Cantos, Chicago, University of Chicago Press, 1991.

RANCIÈRE, Jacques, The Politics of Aesthetics, London, Bloomsbury Academic, 2013.

REDMAN, Tim, Ezra Pound and Italian Fascism, Cambridge, Cambridge University Press, 1991.

\section{NOTES}

1. The composition of the Cantos almost spans Ezra Pound's entire poetic career until his death in 1972 : the writing begins as early as 1915 and a first instalment is published in 1922. Along with a series of essays on historical figures or on economics, inspired by his readings on Social Credit or of Karl Marx's Capital, the work constantly engages issues of politics and the part to be played by the poet in civil society. The turn to Fascism after 1924 severely puts into question what originally presents itself as a critique of post WWI geopolitics.

2. A Companion to The Cantos of Ezra Pound, Berkeley, University of California Press, 1980.

3. Ezra Pound and Italian Fascism, Cambridge, Cambridge University Press, 1991.

4. "Sigismundo Pandolfo Malatesta, 1417-1468, Lord of Rimini, Fano, and Cesena, famous condotierre, military engineer, and patron of the arts, for Pound the "factive personality." [...]Though only 13[...], Sigismundo with his small force succeeded in dispersing the papal troops. This incident marked the beginning of a lifelong struggle to defend his domain against all comers, a struggle that reached climactic points during the reigns of Pius II and Paul II. [...] Sigismundo, although in many ways a heroic figure in his lifelong struggle against superior odds, was by no means without blemishes of character which can even be discerned between the lines of the Malatesta Cantos, but up to Pound's day Pius II's paranoically biased misrepresentation of him, which was parroted by later historians without the slightest attempt at verification, was still being taught in the schools even though a popular attempt to straighten the record had been undertaken by Yriarte in 1882, followed by Edward Hutton in 1906, which appears to have been the first to catch Pound's attention." (Terrell 37). Rainey adds to this that Pound's retrieval of the legend of sigismundo parallels and even intersects with interest expressed by Fascist 
propagandists of the time, most notably Antonio Beltramelli, Benito Mussolini first biographer (218).

5. In this perspective, see Guide to Kulchur (1938), which at the same time exalts and debunks high culture, thus participating in this paradoxical double process of aestheticization and politicization.

6. The concept of "impact" is directly lifted from Ezra Pound's own theorization of the modes of reception of his work, as in the title chosen for his essays in 1960 : Impact: Ezra Pound's Essays on Ignorance \& the Decline of American Civilization.

7. The modern American cheap sneers at democracy and at some of Jefferson's slogans are based on the assumption that Jefferson's ideas were idées fixes. // Attacks on Jefferson's sincerity made during his lifetime were made by the same type of idiot, on precisely the opposite tack. I mean because they weren't idées fixes, and because Jefferson was incapable of just that form of stupidity. //An idée fixe is a dead, set, stiff, varnished "idea" existing in a vacuum. // The ideas of genius, or of "men of intelligence" are organic and germinal, the "seed" of the scriptures. // You put one of these ideas somewhere, i.e. somewhere in a definite space and time, and something begins to happen." (Jefferson and/or Mussolini 21)

8. I keep gathering the fragments of the mosaic (my translation, since it is not in the English version).

9. "The real life in regular verse is an irregular movement underlying." (Jefferson and/or Mussolini 94)

10. “Genius, as I had recently occasion to say apropos Francisci's work with a ciné-camera, is the capacity to see ten things where the ordinary man sees one, and where the man of talent sees two or three, PLUS the ability to register that multiple perception in the material of his art. [...] Jefferson was polumetis, many-minded [...]." (Jefferson and/or Mussolini 88-89)

11. "With all the superficial differences that could very well be in this world neither T.J. nor B.M. is a Gongorist, i.e. one who obscure the whole by the details. // Jefferson as a lawyer and as a law scholar used legalities and legal phrases as IMPLEMENTS, Mussolini as an ex-editor uses oratory, and by comparison with Italian habits of speech ("these damned Eyetalyan intellexshuls that think they are still contemporaries of Metastasio"), that oratory is worth study" (Jefferson and/or Mussolini 65). Do note the suppression from the Italian version of the derogatory comment in between brackets, which is not only a diplomatic concession to Italian susceptibilities but also the mark of an evolution in Pound's conception of the Italian language as the vehicle for aestheticized politics.

12. "I mean the perception is not simply the perception of one's own subjectivity, but there is an object which others perceive. [...] It may be, of course, that one's intuition takes in the whole, and sees straight, whereas one's verbal receiving-station or one's logic deals with stray detail, and that one's intuition can't get hold of the particular, or anything particular, but only of the whole." (Jefferson and/or Mussolini 49-50)

13. "Why, you will ask, should I, a correct Jeffersonian and Confucian, accept all these so different details ?" (Jefferson and/or Mussolini 46)

14. "Frobenius, in the interview referred to, said that Mussolini's miracle had been that of reawakening the sense of responsibility. I cite Frobenius merely to have my own opinion independently delivered by another man who knows enough of the facts to form an intelligent judgment" (Jefferson and/or Mussolini 39). The Italian version shows an evolution towards more assertiveness : the term "judgment" and its implications of subjectiveness is suppressed. 


\section{ABSTRACTS}

Inscribed within the framework of Ezra Pound's theory of the "luminous detail," historical facts are placed under the sign of a highly idiosyncratic master narrative, which ties in with a politics of aethetics, after Jacques Rancière but also in keeping with Benjaminian evaluations of the political uses of aesthetics. Mainly focused on Jefferson and/or Mussolini and a comparative study of the American edition and its Italian translation Jefferson e Mussolini, this article considers the possibility of a Poundian perilous fascination for an aestheticized vision of politics, yoking together the conception of state and the construction of the poem, under similar demands of beauty and aesthetic elegance, at the expense of ethical imperatives.

Inscrits dans le cadre de la théorie poundienne du « détail lumineux ", les faits historiques sont placés sous le signe d'un grand récit idiosyncrasique qui ressort d'une politique de l'esthétique, au sens où l'entend Jacques Rancière, mais aussi en droite ligne des réflexions de Walter Benjamin sur les utilisations politiques de l'esthétique. Par la comparaison entre Jefferson and/or Mussolini et sa traduction italienne, Jefferson e Mussolini, cet article envisage la possibilité d'une fascination poudienne extrêmement risquée pour une vision esthétisante de la politique, qui couple la conception de l'État et la construction du poème, en vertu d'exigences similaires de beauté et d'élégance esthétique, aux dépens des impératifs éthiques.

\section{INDEX}

Keywords: Ezra Pound, Politics, Aesthetics, Fascism, Poetry

Mots-clés: Ezra Pound, politique, esthétique, fascisme, poésie

\section{AUTHOR}

HÉLÈNE AJI

Université Paris Ouest-Nanterre La Défense 